\title{
Molecular detection of marine nematodes from environmental samples: overcoming eukaryotic interference
}

\author{
Punyasloke Bhadury ${ }^{1,2,5, *}$ Melanie C. Austen ${ }^{1}$, David T. Bilton ${ }^{2}$, \\ P. John D. Lambshead ${ }^{3}$, Alex D. Rogers ${ }^{4,6}$, Gary R. Smerdon ${ }^{1}$ \\ ${ }^{1}$ Plymouth Marine Laboratory, Prospect Place, The Hoe, Plymouth PL1 3DH, UK \\ ${ }^{2}$ School of Biological Sciences, University of Plymouth, Drake Circus, Plymouth PL4 8AA, UK \\ ${ }^{3}$ Nematode Research Group, Department of Zoology, The Natural History Museum, Cromwell Road, London SW7 5BD, UK \\ ${ }^{4}$ British Antarctic Survey, High Cross, Madingley Road, Cambridge CB3 0ET, UK \\ ${ }^{5}$ Present address: Department of Geosciences, Princeton University, New Jersey 08544, USA \\ ${ }^{6}$ Present address: Institute of Zoology, Zoological Society of London, Regent's Park, London NW1 4RY, UK
}

\begin{abstract}
Nematodes form an important and dominant component of many benthic marine ecosystems, but are frequently neglected by marine ecologists because of the time-consuming nature of their identification. Molecular techniques provide powerful tools for the rapid assessment of biodiversity, although few attempts have been made to apply these to marine meiofauna. We evaluated the success of 2 primer sets in amplifying nematode 18S rRNA from DNA templates extracted directly from marine and estuarine sediments. PCR products were separated using denaturing gradient gel electrophoresis (DGGE), and some of the intense DGGE bands were excised, cloned and sequenced to confirm their nematode origin. Initially, other eukaryotic 18S rRNA regions co-amplified with those from nematodes, possibly as a result of the high relative abundance and biomass of other organisms in the studied sediments. These problems were overcome by designing and evaluating consensus primers that selectively amplified nematode ribosomal regions from environmental DNA. Approximately 10 to 12 taxa from each site were detected in the denaturing gel in this study. Tentative affiliations of some the DGGE bands re-amplified using nematode-specific primers were determined by comparing with known marine nematode $18 \mathrm{~S}$ rRNA sequences in a phylogenetic tree. Our study demonstrates for the first time that PCR combined with DGGE can be used to explore the community composition of many meiofaunal groups, such as nematodes, from DNA extracted directly from environmental samples.
\end{abstract}

KEY WORDS: Marine nematodes · Environmental DNA · Ribosomal primers · Denaturing gradient gel electrophoresis · DGGE · Eukaryotic interference · Diversity

Resale or republication not permitted without written consent of the publisher

\section{INTRODUCTION}

Marine nematodes play an important role in the ecology of seas and estuaries (Coull 1999), being diverse, universally abundant and often showing sensitive responses to environmental changes (Austen 2004, Lambshead 2004). They are becoming increasingly important as indicators for environmental monitoring, particularly in relation to marine pollution (Tietjen \& Lee 1984, Lambshead 1986, Austen \&
McEvoy 1997, Bongers \& Ferris 1999, Boyd et al. 2000, Ahnert \& Schriever 2001). Despite such attributes nematode taxonomy is relatively time-consuming, making studies of nematode diversity in marine ecosystems somewhat laborious (Coomans 2002, Floyd et al. 2002, Cook et al. 2005). Given these difficulties, it is surprising that to date there has been limited application of molecular techniques in the rapid assessment of marine nematode diversity from estuarine and marine sediments. In the past, molecular tech- 
niques have been successfully applied to address questions of diversity in marine eukaryotes such as protists and picoplanktons (Díez et al. 2001, Gast et al. 2004, Countway et al. 2005). To date, only Cook et al. (2005) have used electrophoretic techniques to study marine nematode diversity. This study relied on extraction of nematodes from sediment prior to ribosomal RNA amplification using universal primers. Meldal (2004) and Cook et al. (2005) used 18S rRNA for barcoding of marine nematodes and molecular phylogenetics, respectively, but there is no report as yet on the use of nematode-specific 18S rRNA primers for amplifying environmental DNA directly extracted from marine and estuarine sediments.

The aim of this study was to establish and extend the potential of molecular ecological approaches for rapid screening of marine nematode diversity from natural environments, and specifically to determine whether nematode diversity could be rapidly assessed from DNA extracted directly from sediments. We employed the 18S rRNA gene as a marker of nematode diversity in this study since its sequences are generally species specific and it contains both conserved (primer design) and variable (taxonomic distinction) regions (Blaxter et al. 1998, Schlötterer 1998, Dorris et al. 1999, Foucher \& Wilson 2002, Cook et al. 2005). PCR amplification was carried out using primers designed from 18S rRNA sequences held online at GenBank and EMBL, and specificity of the consensus primers was determined by excision, amplification and sequencing of bands resolved by denaturing gradient gel electrophoresis (DGGE). This technique is widely used in microbial ecology (Muyzer et al. 1993, Schafer et al. 2001, Savin et al. 2004, Postec et al. 2005), but has had limited application to studies of benthic eukaryotes, despite its obvious potential.

\section{MATERIALS AND METHODS}

Sample location. Sediments (mud/mud-sand) were collected subtidally from a variety of marine and estuarine locations in SW England: Saltash, Tamar estuary (1 to $5 \mathrm{~m}$ depth) $\left(50^{\circ} 24^{\prime} \mathrm{N}, 4^{\circ} 12^{\prime} \mathrm{W}\right)$, Plymouth Sound at Jennycliff (10 $\mathrm{m}$ depth) $\left(50^{\circ} 20^{\prime} \mathrm{N}, 4^{\circ} 08^{\prime} \mathrm{W}\right)$, Plymouth Breakwater (15 m depth) $\left(50^{\circ} 20^{\prime} \mathrm{N}, 4^{\circ} 08^{\prime} \mathrm{W}\right)$, and off Rame Head (50 m depth) $\left(50^{\circ} 17^{\prime} \mathrm{N}, 4^{\circ} 17^{\prime} \mathrm{W}\right)$; and also from North England, at the National Marine Monitoring Programme (NMMP) site in the Humber estuary (70 $\mathrm{m}$ depth) $\left(54^{\circ} 00^{\prime} \mathrm{N}, 2^{\circ} 00^{\prime} \mathrm{E}\right)$. All samples were taken from surface sediment collected using a Van Veen grab, and sediment samples were immediately preserved in $98 \%$ molecular grade ethanol (Hayman Limited).
Extraction of environmental DNA from sediment samples. Environmental DNA was extracted from $0.5 \mathrm{~g}$ sediment for each site using the FastDNA Spin Kit (Qbiogene), following the manufacturer's recommendations. DNA from each site was eluted in $50 \mu \mathrm{l}$ of DES (DNase/pyrogen free water). Subsequently, DNA concentration from all the sites was adjusted to $45 \mu \mathrm{g} \mathrm{ml}^{-1}$ following quantification in a spectrophotometer and then used for PCR amplification.

Primers for DGGE. DGGE works optimally with fragments less than $1 \mathrm{~kb}$ in size (Potts 1996). We used 2 sets of primers: (1) G18F (forward) (5'-GCTTGTCTCAAAGATTAAGCC-3') (Position 30 to 49 in relation to Caenorhabditis elegans sequence) and 22R (reverse) (5'-GCCTGCTGCCTTCCTTGGA-3') (Position 429 to 411 in relation to $C$. elegans) (Blaxter et al. 1998); (2) MN18F (forward) (5'-CGCGAATRGCTCATTACAACAGC-3') (Position 111 to 123 in relation to C. elegans) and 22R (reverse). The first comprises the universal primer set which produces $400 \mathrm{bp}$ amplicons, and has been used in the past for nematode phylogenetics as well as for studying diversity using electrophoretic techniques (Blaxter et al. 1998, Meldal 2004, Cook et al. 2005). In the case of the second set, the forward primer is more nematode specific and has been designed on consensus nematode ribosomal sequences and produces an amplicon of approximately $345 \mathrm{bp}$. The forward primer in this case is placed between Positions 111 to 123 in relation to the $C$. elegans sequence. The ClustalX program (Thompson et al. 1997, Jeanmougin et al. 1998) was used to construct an alignment containing fulllength nematode 18S rRNA sequences and 18S rRNA sequences from fungal taxa that were picked up in DGGE analysis. A conserved region among nematode 18S rRNA sequences was selected for forward primer design that is absent in the fungal sequences (see alignment in Fig. 1). Annealing temperature and stability of the PCR primer site was examined using PRIMER 3 (Rozen \& Skaletsky 2000). The specificity of the newly designed forward primer was reexamined using BLAST search, whereby the primershowed only significant similarities across different nematode taxa. The GenBank and EMBL accession numbers used to design the nematode-specific primers are Metachromadora sp.: Nematoda, AF036595; Daptonema procerus: Nematoda, AF047889; Sabatieria pulchra: Nematoda, AY854234; Plectus acuminatus: Nematoda, AF037628; Monohystera riemanni: Nematoda, AY593938; Rhinocladiella aquaspersa: Fungus, U20512; Syspastospora parasitica: Fungus, AY015623; Paecilomyces fumosoroseus: Fungus, AB233338. The nematode-specific forward primer binds around $100 \mathrm{bp}$ inward from the 5' end of the $18 \mathrm{~S}$ rRNA molecule. 


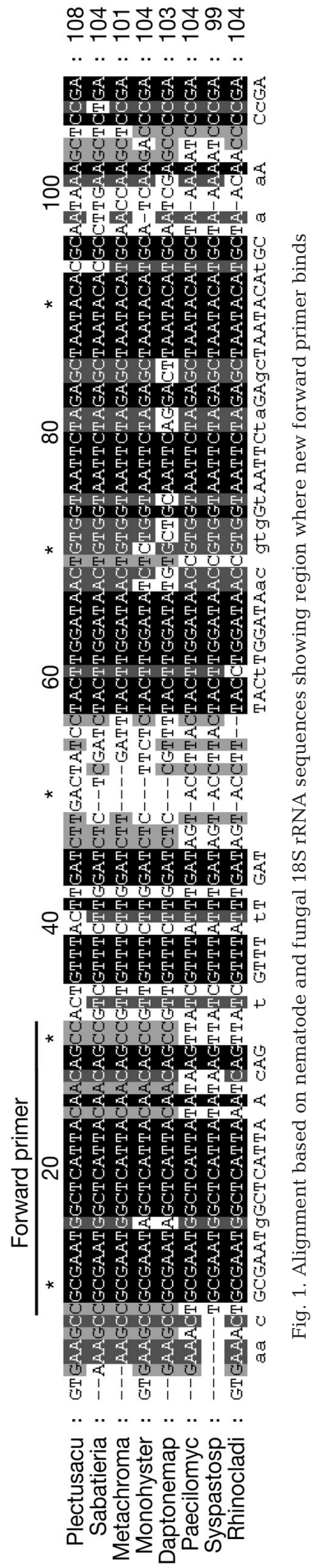

The forward primers for DGGE (G18FGC and MN18F) were synthesised with the addition of a 40 base pair GC clamp (5'-CGCCCGCCGCG CCCCGCGCCCGCCCCGCCGCCCCCGCCCC-3') at the 5' end to prevent complete denaturation of the amplicons under denaturing conditions (Myers et al. 1985, Sheffield et al. 1989).

Amplification of 18S rRNA gene for DGGE analysis. DNA extracted from each site was amplified in a total volume of $50 \mu$ l using the G18FGC, 22R and MN18FGC and 22R primers that have been designed to anneal to conserved regions of the gene. The annealing temperature of the primers was initially optimised using DNA templates from different marine nematode taxa prior to DGGE. PCR reactions were performed on $0.5 \mu \mathrm{l}$ aliquots of the extracted DNA from each site by adding $5 \mu \mathrm{l}$ Pfu buffer, $5 \mu \mathrm{l}$ $2 \mathrm{mM}$ dNTPs, $2 \mu \mathrm{l}$ of each of the

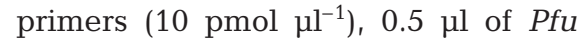
polymerase and Milli-Q water to a final volume of $50 \mu \mathrm{l}$. Amplifications were performed in a PTC-100 programmable thermal cycler (MJ Research). The following programme was used for amplification: $4 \mathrm{~min}$ at $95^{\circ} \mathrm{C}, 36$ cycles of $1 \mathrm{~min}$ at $94^{\circ} \mathrm{C}, 1 \mathrm{~min}$ at $56^{\circ} \mathrm{C}, 90 \mathrm{~s}$ at $72^{\circ} \mathrm{C}$, and finally 1 cycle of $2 \mathrm{~min}$ at $56^{\circ} \mathrm{C}$ and $30 \mathrm{~min}$ at $72^{\circ} \mathrm{C}$ followed by a holding temperature of $4^{\circ} \mathrm{C}$. The PCR products were analysed in $1 \%$ agarose gel prior to DGGE analysis.

DGGE analysis. DGGE analysis was performed on amplified DNA templates using the Bio-Rad DCode ${ }^{\mathrm{TM}}$ Universal Detection System according to the manufacturer's instructions. A 25 to $60 \%$ gradient was used in this study. PCR product (15 $\mu \mathrm{l})$ from each of the sampling stations was loaded into gel. Gels were stained with SYBR Gold nucleic acid stain (Invitrogen). Electrophoresis was carried out at $60 \mathrm{~V}$ for $16 \mathrm{~h}$ at $60^{\circ} \mathrm{C}$. Gels were visualised and recorded using a SYNGENE gel documentation system.

Cloning and DNA sequencing. Dominant bands from the denaturing gel were cut, resuspended in $20 \mu \mathrm{l}$ of Milli-Q water and left overnight at $4^{\circ} \mathrm{C}$. Subsequently, $2 \mu \mathrm{l}$ from each elute was used as template for PCR amplification. Re-amplified PCR fragments were cloned using the pGEM-T Easy vector system (Promega). Prior to cloning, purity of the re-amplified bands was checked by electrophoresis in denaturing gels. Plasmid DNA containing the inserts were cycle sequenced using BigDye Terminator Kit (Applied Biosystems). Cycle sequencing reactions were cleaned using the Wizard Magnesil ${ }^{\mathrm{TM}}$ system (Promega). Sequencing was carried out in both directions using M13F and M13 primers in an ABI Hitachi 3100 genetic analyzer. The results of the sequences were then compared with those of known 18S rRNA nematode sequences held online at GenBank, EMBL, DDBJ and PDB using the BLAST query engine (available at: www.ncbi. nlm.nih.gov/BLAST).

Construction of phylogenetic tree. A phylogenetic tree was constructed using the sequences from the excised bands (amplified using MN18F and $22 \mathrm{R}$ primers and $\mathrm{G} 18 \mathrm{~F}$ and $22 \mathrm{R}$ primers) and additional marine nematode 18S rRNA sequences (Bhadury 2005) as well as sequences from Meldal (2004) and Cook et al. (2005) publications held online in GenBank and EMBL databases. Prior to phylogenetic analysis, nematode sequences were aligned in ClustalX using default parameters (Thompson et al. 1997, Jeanmougin et al. 1998). A neighbourjoining tree was constructed with the program MEGA Version 3.0 (Kumar et al. 2004) using nucleotide gamma corrected Kimura distance parameters (Blaxter et al. 1998).

\section{RESULTS}

The DNA yield for sediment samples from Tamar estuary, Plymouth Breakwater, Jennycliff, Rame Head and the NMMP site were 129.9, 45.0, $57.3,119.4$ and $45.0 \mu \mathrm{g} \mathrm{ml}{ }^{-1}$, respectively. 


\section{Ribosomal diversity from DNA samples amplified using G18FGC and 22R primers}

DNA templates from Jennycliff (JCF), Rame Head (RH), Plymouth Breakwater (BW) and Saltash, Tamar estuary (SH) amplified using G18FGC and 22R primers showed a characteristic banding pattern for each site. Based on DGGE banding patterns, the ribotype diversity seemed to differ between sites, with certain bands more obvious at certain sites (Fig. 2). The majority of the excised bands (assigned with reference numbers on the gel) showed high sequence similarity with the nematode sequences held online at GenBank and EMBL; however, 3 of the sequences showed similarities with the fungus Paecilomyces fumosoroseus (99\% similarity), Rhinocladiella aquaspersa (98\% similarity) and Syspastospora parasitica (98\% similarity). Additionally, 2 sequences showed similarities with an

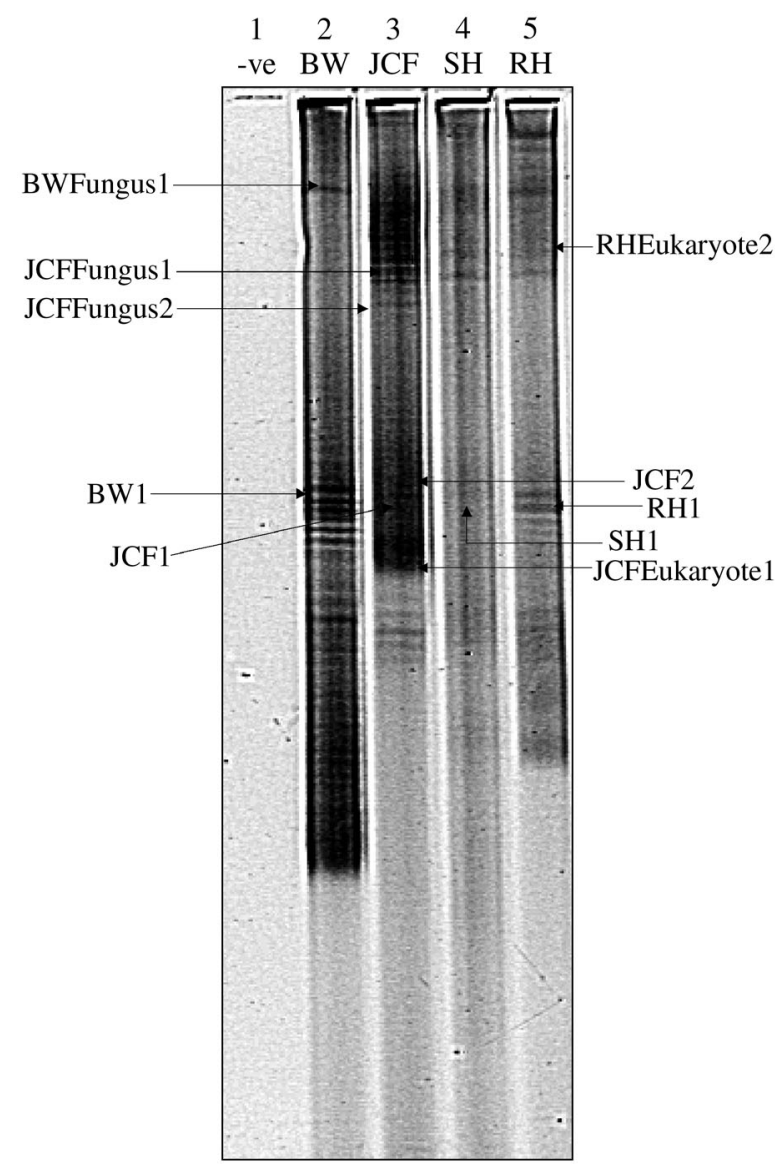

Fig. 2. Banding patterns of marine nematode communities from 5 environmental stations amplified using G18FGC and 22R primers; Lane 1: negative, to check any contamination; Lane 2: community pattern for Plymouth Breakwater (BW); Lane 3: pattern for Jennycliff (JCF); Lane 4: community pattern for Saltash, Tamar estuary (SH); Lane 5: pattern for Rame Head (RH). Arrows indicate bands that have been extracted and sequenced uncultured stramenopile clone IAFDv26 (99\% similarity) and an uncultured marine eukaryotic clone mj223 (99\% similarity), respectively. The nematode sequences have been submitted to EMBL (Accession Nos. AJ966665 [BW1], AJ966666 [JCF1], AJ969109 [JCF2], AM039438 [RH1] and AM039439 [SH1]). Fungal and other eukaryotic sequences reported in this paper have been submitted to EMBL (Accession Nos. AJ965493 [JCFFungus1], AJ965494 [JCFFungus2], AJ965671 [BWFungus1], AJ971292 [JCFEukaryote1] and AJ971293 [RHEukaryote 2]).

\section{Ribosomal diversity from DNA samples amplified using MN18FGC and 22R primers}

The ribosomal diversity differed between all 5 sites in terms of DGGE banding patterns, with certain bands prevalent at certain sites (Fig. 3). Approximately 10 bands could be distinguished in the gel, representing 10 putative taxa for $\mathrm{RH}, \mathrm{NMMP}$ and $\mathrm{SH}$, whereas for JCF and BW between 7 and 8 taxa were distin-

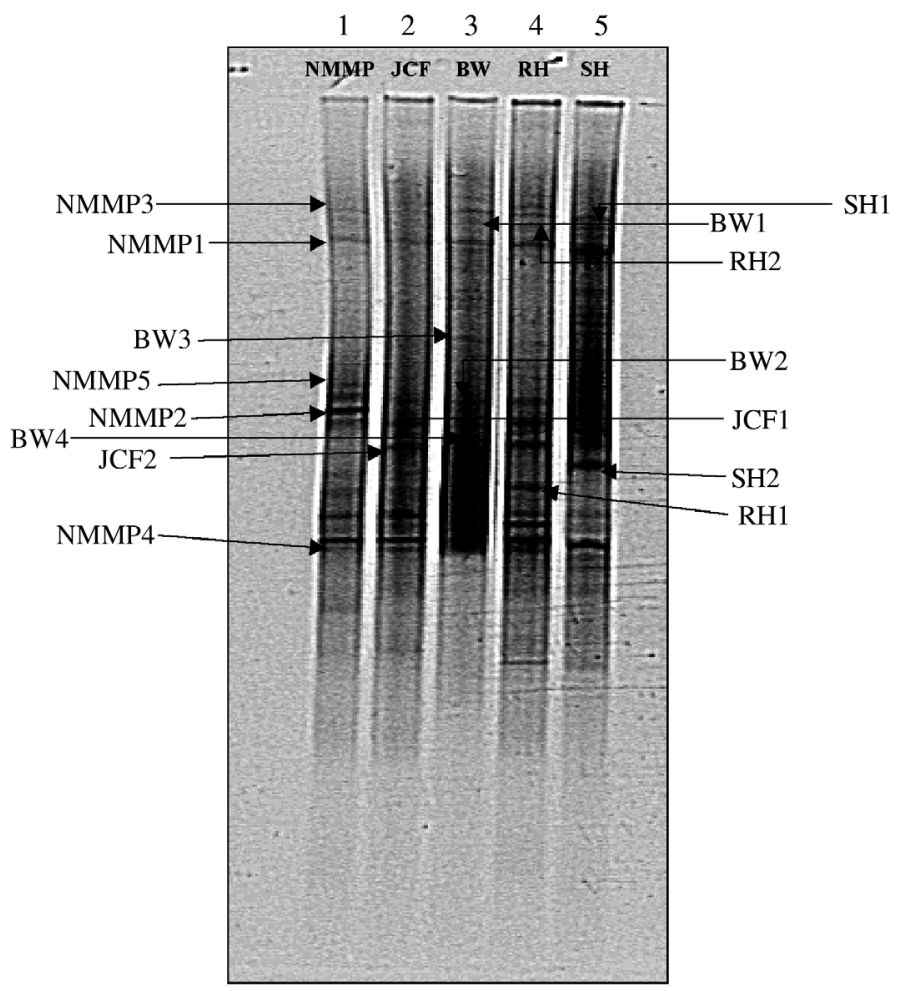

Fig. 3. Banding patterns of marine nematode communities from 5 environmental stations amplified using MN18FGC and 22R primers; Lane 1: community pattern for National Marine Monitoring Programme site in the Humber estuary (NMMP); Lane 2: pattern for Jennycliff (JCF); Lane 3: community pattern for Plymouth Breakwater (BW); Lane 4: community pattern for Rame Head (RH); Lane 5: pattern for Saltash, Tamar estuary ( $\mathrm{SH})$. Arrows indicate bands that have been extracted and sequenced 
guished. Here, all extracted bands showed high sequence similarity to the available nematode sequences held online at GenBank and EMBL. Coamplification of other eukaryotic 18S rRNA including fungi was not recorded in this case. The placement of some of these sequences amplified using MN18F and 22R primers in the phylogenetic tree (Fig. 4) suggests that they share high sequence similarity with Sabatieria celtica and Setosabatieria hilarula (JCF2),

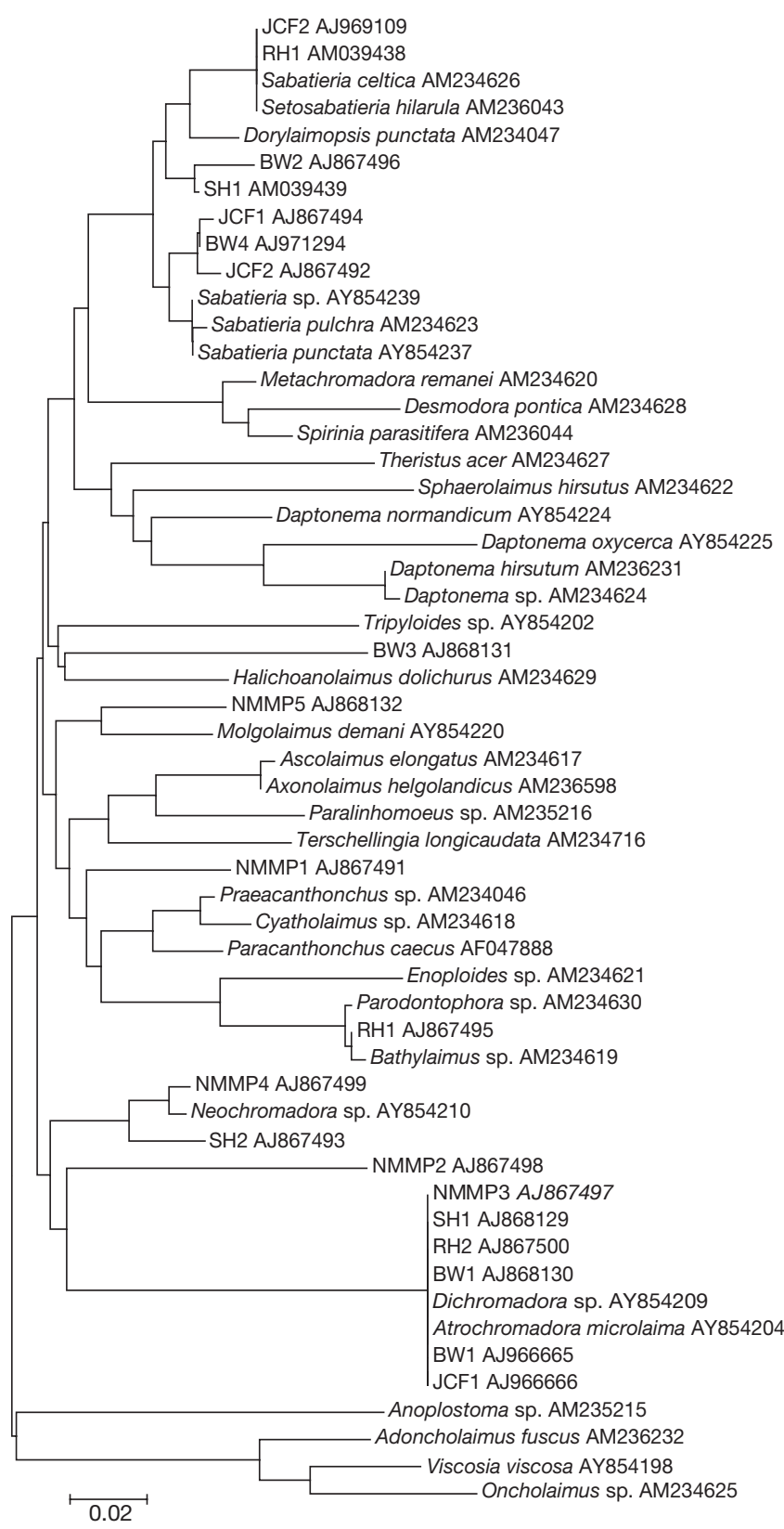

Fig. 4. Phylogenetic tree showing relationship between DGGE bands amplified using nematode specific primer (MN18F-22R) and universal primers (G18F-22R) (18S rRNA) and most similar sequences of known nematodes. Distance scale indicates 0.02 substitutions site ${ }^{-1}$
Halichoanolaimus dolichurus (BW3), Bathylaimus sp. (RH1), Dichromadora sp., and Atrochromadora microlaima (SH1, NMMP3, BW1, RH2), Molgolaimus demani (NMM5) and Neochromadora sp. (NMMP4). The marine nematode sequences reported in this paper have been deposited in the EMBL database and are detailed in Fig. 4.

\section{DISCUSSION}

The main purpose of this study was to investigate the effectiveness of DGGE for the rapid assessment of nematode diversity following environmental DNA extraction and PCR amplification. Pfu DNA polymerase was used in the study during the amplifications because of its proofreading properties (Lundberg et al. 1991, Flaman et al. 1994, Cline et al. 1996). With the first primer set, co-amplification of fungal 18S rRNA as well as other eukaryotic ribosomal regions was also recorded from 3 sites in the study (Jennycliff, Plymouth Breakwater and Rame Head). This indicated that the consensus primers initially designed on available nematode $18 \mathrm{~S}$ rRNA sequences were picking up ribosomal regions from other eukaryotes, possibly because of the high abundance of the 18S rRNA gene from these organisms in the environmental DNA.

As a result, a forward primer was redesigned that could selectively amplify nematode ribosomal regions from estuarine and marine sediments. A new region from the $5^{\prime}$ end of the nematode 18S rRNA was selected for consensus primer designing, whereby the variable regions were flanked by conserved regions. The redesigned forward primer along with the reverse primer were tested on DNA templates for PCR and subsequent DGGE analysis. Specificity of the second primer set was evaluated by band excision and subsequent amplification and sequencing. All bands showed high sequence similarity with nematode sequences, indicating that the primers as well as the DGGE technique are capable of targeting and resolving 18S rRNA of marine nematodes from environmental samples. Additionally, the nematode sequences detected by the specific primers in DGGE gels (MN18FGC-22R) were also detected in gels following PCR with the universal primers (G18FGC-22R), indicating that the newly designed primer combinations were not excluding sequence types that were readily obtained by the universal primers.

As mentioned in the last subsection of 'Results', DGGE of PCRs using nematode-specific primers detected only 8 to 10 taxa at each site. This contrasts with published data available for Rame Head, Jennycliff and Saltash, Tamar estuary, where the mean numbers of species were 35, 35 and 18, respectively 
from $50 \mathrm{~g}$ (Austen \& Warwick 1989, Austen et al. 2003) or $70 \mathrm{~g}$ (Austen \& McEvoy 1997) of sediment. In a previous study, Cook et al. (2005) recorded 25 different taxa from a sediment sample in Tamar estuary, SW England, whereas DGGE analysis of the same sample only detected 15 . Despite this, approximately 5 to 10 species constitute more than $80 \%$ of nematode abundance at these sites (Austen \& Warwick 1989, M. C. Austen unpubl.), such patterns being typical for subtidal marine sediments (Heip et al. 1985).

It appears, therefore that our approach resolves only these dominant species and not the less abundant taxa (Austen 1986, Austen \& Warwick 1989). This conclusion is supported by the phylogenetic tree, where some of the sequences resolved into groups of known marine nematode sequences that are dominant in these environments. Some of the nematode taxa that dominate estuarine and marine sediments around SW England are Sabatieria celtica, S. ornata, S. pulchra, Terschellingia longicaudata, Daptonema oxycerca, Metachromadora sp., Dichromadora sp., and Atrochromadora microlaima (Warwick \& Price 1979, Austen 1986, Austen \& Warwick 1989, Bhadury 2005, Cook et al. 2005). Most of these nematodes play a major role in marine decomposition processes through the direct consumption of detritus and, more importantly, through grazing (and hence increasing the productivity of) heterotrophic bacteria involved in decomposition (Yeates \& Coleman, 1982, Austen 2004). Additionally, these organisms in conjunction with other meiofauna mechanically break down detrital particles and cause them to be more susceptible to increased bacterial action (Coull 1999).

It appears then that the DGGE measure of diversity is rapid but will probably only be effective for monitoring patterns of diversity within the dominant component of the nematode community. These results are similar to those achieved using DGGE in microbial ecology studies, whereby the true diversity probably remains underestimated in complex communities as the taxa present in low abundance generally remain undetected (Muyzer et al. 1993, Holben et al. 2004).

In conclusion, the present study provides further evidence that molecular techniques can provide a rapid assessment of marine nematode community composition from the study of environmental DNA. Our approach represents a significant advance over that of Cook et al. (2005), since it avoids the time-consuming and expensive steps of nematode extraction and subsequent DNA extraction and amplification of individuals. Necessarily, this new approach has required the development of more specific primers than those used in previous studies (Foucher \& Wilson 2002, Waite et al. 2003, Cook et al. 2005). Like the approach of Cook et al. (2005), our method is limited to the detection of the more abundant species in the community, but is nevertheless a useful, rapid method for the assessment of composition of, and change in, nematode assemblages.

Acknowledgements. P.B. acknowledges Plymouth Marine Laboratory (PML) for the provision of a PhD Studentship. This is a contribution towards the PML Functional Biodiversity Project and to the Marine Genomics Europe, Network of Excellence funded under the 6th Framework Programme of the European Union.

\section{LITERATURE CITED}

Ahnert A, Schriever G (2001) Response of abyssal Copepoda Harpacticoida (Crustacea) and other meiobenthos to an artificial disturbance and its bearing on future mining for polymetallic nodules. Deep-Sea Res II 48:3779-3794

Austen MC (1986) Factors affecting meiobenthic community structure in the Tamar estuary. PhD thesis, University of Exeter

Austen MC (2004) Natural nematode communities are useful tools to address ecological and applied questions. Nematol Monogr Perspect 2:1-17

Austen MC, McEvoy AJ (1997) The use of offshore meiobenthic communities in laboratory microcosm experiments: response to heavy metal contamination. J Exp Mar Biol Ecol 211:247-261

Austen MC, Warwick RM (1989) Comparison of univariate and multivariate aspects of estuarine meiobenthic community structure. Estuar Coast Shelf Sci 29:23-42

Austen MC, Parry DM, Widdicombe S, Somerfield PJ, Kendall MA (2003) Macrofaunal mediation of effects of megafaunal bioturbation on nematode community structure. Vie Milieu 53:201-210

Bhadury P (2005) Molecular resolution of marine nematodes for improved assessment of biodiversity. PhD thesis, University of Plymouth

Blaxter ML, De Ley P, Garey JR, Liu LX and 8 others (1998) A molecular evolutionary framework for the phylum Nematoda. Nature 392:71-75

Bongers T, Ferris H (1999) Nematode community structure as a bioindicator in environmental monitoring. Trends Ecol Evol 14:224-228

Boyd SE, Rees HL, Richardson CA (2000) Nematodes as sensitive indicators of changes at dredged material disposal sites. Estuar Coast Shelf Sci 51:805-819

Cline J, Braman JC, Hogrefe HH (1996) PCR fidelity of pfu DNA polymerase and other thermostable DNA polymerases. Nucleic Acid Res 24:3546-3551

Cook AA, Bhadury P, Debenham NJ, Meldal BHM and 5 others (2005) Denaturing gradient gel electrophoresis as a tool for the identification of marine nematodes. Mar Ecol Prog Ser 291:103-113

Coomans A (2002) Present status and future of nematode systematics. Nematology 5:573-582

Coull BR (1999) Role of meiofauna in estuarine soft-bottom habitats. Aust Ecol 24:327-343

Countway PD, Gast RJ, Savai P, Caron DA (2005) Protistan diversity estimates based on 18S rRNA from seawater incubations in the Western North Atlantic. J Eukaryot Microbiol 52:95-106

Díez B, Pedros-Alio C, Marsh TL, Massana R, Diez B, PedrosAlio C, Marsh TL, Massana R (2001) Application of dena- 
turing gradient gel electrophoresis (DGGE) to study the diversity of marine picoeukaryotic assemblages and comparison of DGGE with other molecular techniques. Appl Environ Microbiol 67:2942-2951

Dorris M, De Ley P, Blaxter M (1999) Molecular analysis of nematode diversity. Parasitol Today 15:188-193

Flaman JM, Frebourg T, Moreau V, Charbonnier F, Martin C, Ishioka C, Friend SH, Iggo R (1994) A rapid PCR fidelity assay. Nucleic Acids Res 22:3259-3260

Floyd R, Abebe E, Papert A, Blaxter ML (2002) Molecular barcodes for soil nematode identification. Mol Ecol 11: 839-850

Foucher A, Wilson M (2002) Development of a polymerase chain reaction-based denaturing gradient gel electrophoresis technique to study nematode species biodiversity using the 18S rDNA gene. Mol Ecol Notes 2:45-48

Gast RJ, Dennnett MR, Caron DA (2004) Characterization of protistan assemblages in the Ross Sea, Antarctica, by denaturing gradient gel electrophoresis. Appl Environ Microbiol 70:2028-2037

Heip C, Vincx M, Vranken G (1985) The ecology of marine nematodes. Oceanogr Mar Biol Annu Rev 23:399-489

Holben WE, Feris KP, Kettunen A, Apajalahati JHA (2004) GC fractionation enhances microbial community diversity assessment and detection of minority populations of bacteria by denaturing gradient gel electrophoresis. Appl Environ Microbiol 70:2263-2270

Jeanmougin F, Thompson JD, Gouy M, Higgins DG, Gibson TJ (1998) Multiple sequence alignment with Clustal X. Trends Biochem Sci 23:403-405

Kumar S, Tamura K, Nei M (2004) MEGA3: integrated software for molecular evolutionary genetics analysis and sequence alignment. Briefings Bioinformatics 5:150-163

Lambshead PJD (1986) Sub-catastrophic sewage and industrial waste contamination as revealed by marine nematode faunal analysis. Mar Ecol Prog Ser 29:247-260

Lambshead PJD (2004) Marine nematode biodiversity. In: Chen ZX, Chen WY, Chen SY \& Dickson DW (eds) Nematology: advances and perspectives, Vol 1: Nematode morphology, physiology and ecology. CABI Publishing, Oxon, p 436-467

Lundberg KS, Shoemaker DD, Adams MW, Short JM, Sorge JA, Mathur EJ (1991) High-fidelity amplification using a thermostable DNA polymerase isolated from Pyrococcus furiosus. Gene 108:1-6

Meldal BHM (2004) Phylogenetic systematics of the phylum Nematoda-evidence from molecules and morphology. $\mathrm{PhD}$ thesis, University of Southampton

Muyzer G, De Waal EC, Uitterlinden AG (1993) Profiling of complex microbial populations by denaturing gradient gel electrophoresis analysis of polymerase chain reaction amplified genes coding for 16S rRNA. Appl Environ Microbiol 59:695-700

Myers RM, Fischer SG, Lerman LS, Manialis T (1985) Nearby

Editorial responsibility: Dittmar Hahn,

San Marcos, Texas, USA all base substitution in DNA fragments joined to a GCclamp can be detected by denaturing gradient gel electrophoresis. Nucleic Acids Res 13:3131-3145

Postec A, Urios L, Lesongeur F, Ollivier B, Querellou J, Godfroy A (2005) Continuous enrichment culture and molecular monitoring to investigate the microbial diversity of thermophiles inhabiting deep-sea hydrothermal ecosystems. Curr Microbiol 50:138-144

Potts WK (1996) PCR-based cloning across large taxonomic distances and polymorphism detection: MHC as a case study. In: Ferraris JD, Palumbi SR (eds) Molecular zoology: advances, strategies, and protocols. John Wiley \& Sons, New York, p 181-194

Rozen S, Skaletsky H (2000) PRIMER 3 on the WWW for general users and for biologist programmers. In: Krawetz S, Misener S (eds) Methods and protocols. Bioinformatics. Humana Press, Totowa, NJ, p 365-368 (also available at: http://Fokker.wi.mit.edu/primer3)

Savin MC, Martin JL, LeGresley M, Giewat M, Rooney-Varga $\mathrm{J}$ (2004) Plankton diversity in the Bay of Fundy as measured by morphological and molecular methods. Microb Ecol 48:51-65

Schafer H, Bernard L, Courties C, Lebaron P and 7 others (2001) Microbial community dynamics in Mediterranean nutrient-enriched seawater mesocosms: changes in the genetic diversity of bacterial populations. FEMS Microbiol Ecol 34:243-253

Schlötterer C (1998) Ribosomal DNA probes and primers. In: Karp A, Esaac PG, Ingram DS (eds) Molecular tools for screening biodiversity, plant and animals. Chapman \& Hall, London, p 265-276

Sheffield VC, Cox DR, Lerman LS, Myers RM (1989) Attachment of a 40-base-pair $\mathrm{G}+\mathrm{C}$ rich sequence (GC-clamp) to genomic DNA fragments by the polymerase chain reaction results in improved detection of single-base changes. Proc Natl Acad Sci USA 86:232-236

Thompson JD, Gibson TJ, Plewniak F, Jeanmougin F, Higgins DG (1997) The CLUSTAL_X windows interface: flexible strategies for multiple sequence alignment aided by quality analysis tools. Nucleic Acids Res 25:4876-4882

Tietjen JH, Lee JH (1984) The use of free-living nematodes as a bioassay for estuarine sediments. Mar Environ Res 11: $233-251$

Waite IS, O'Donnell AG, Harrison A, Davies JT and 11 others (2003) Design and evaluation of nematode 18S rRNA primers for PCR and denaturing gradient gel electrophoresis (DGGE) of soil community DNA. Soil Biol Biochem 35:1165-1173

Warwick RM, Price R (1979) Ecological and metabolic studies on free-living nematodes from an estuarine mud-flat. Estuar Coast Mar Sci 9:257-271

Yeates GW, Coleman DC (1982) Nematodes in decomposition. In: Freckman DW (ed) Nematodes in soil ecosystems. University of Texas, Austin, TX, p 55-80

Submitted: June 26, 2005; Accepted: March 24, 2006

Proofs received from author(s): July 17, 2006 